\title{
PENDIDIKAN KEWARGANEGARAAN BERBASIS MULTIKULTURAL DI MTS AL HAMID BANJARMASIN
}

\author{
Sigit Triyono \\ Dosen FKIP Universitas Lambung Mangkurat Banjarmasin \\ Jalan Brigjen H. Hasan Basri Banjarmasin
}

\begin{abstract}
This study used a qualitative approach naturalistic sociometry test, the subject of research is the principal, vice-principal areas of curriculum / student, students in the academic year 2015/2016, for the principal one person, the vice principal curriculum areas 1, vice-principals student field 1, while for learners 30 people. Data collection techniques gained through observation, interviews, documentation, test sosiomentri and literature. The results of this study to prepare schools in addressing the differences among them are the principal called a meeting to the board of teachers and their vice principal of student and curriculum to discuss the creation of lesson plans which include a plan of material to be taught and the objectives to be achieved, while the curriculum used by the MTs Al Hamid Banjarmasin ie curriculum SBC Plus, learning to use the curriculum in English. The role of the vice principal of student field of multicultural education in assisting the implementation of directly applied in the form of extracurricular activities. Evaluation of multicultural education in MTs Al Hamid Banjarmasin has been successfully implementing the learning process of multicultural education. This is evident in the daily Siswan and teachers despite its students come from different social strata, but can get along and respect each other regardless of differences.
\end{abstract}

Keywords: Planning, Implementation, Evaluation, Multicultural Education and Civics.

\section{PENDAHULUAN}

Indonesia adalah salah satu negara multi-suku, multi-etnik, multi-agama juga multi-budaya. Masing-masing budaya yang berkembang pada suatu wilayah tertentu memiliki kekhasan tersendiri yang berbeda dengan lainnya. Keanekaragaman kultural di negara kesatuan Republik Indonesia dalam dunia 
pendidikan merupakan aset atau kekayaan budaya bangsa, juga sekaligus merupakan potensi pengembangan dalam sektor pendidikan, budaya, ekonomi hingga politik. ${ }^{1}$

Kebenaran dari pernyataan di atas dapat dilihat dari sosio-kultur maupun geografis yang begitu beragam dan luas dari jumlah pulau yang ada di wilayah NKRI sekitar kurang lebih 13.000 pulau besar dan kecil, dan jumlah penduduk kurang lebih 200 juta jiwa, terdiri dari 300 suku yang menggunakan hampir 200 bahasa yang berbeda.

Kemajemukan tersebut pada satu sisi merupakan kekuatan sosial (social power) dan keragaman yang indah apabila satu sama lain bersinergi dan saling bekerja sama, hidup harmonis dan stabil untuk membangun bangsa. Konsep majemuk, menggambarkan budaya yang lebih dari satu (many). Keragaman menunjukan bahwa keberadaan yang lebih dari satu berbeda-beda, heterogen, dan bahkan tak dapat disamakan. Kemajemukan ini, ditandai dengan banyaknya agama, suku bangsa, budaya, kebiasaan/tradisi dan kedaerahan.

Pada sisi lain, kemajemukan tersebut apabila tidak dikelola dan dibina dengan tepat, bakal menjadi pemicu dan penyulut konflik dan kekerasan yang dapat menggoyahkan sendi-sendi kehidupan berbangsa.

Serentetan konflik dan kekerasan yang terjadi di beberapa daerah merupakan contoh kekerasan dan konflik horizontal yang telah menguras energi dan merugikan tidak saja jiwa dan materi, tetapi juga mengorbankan keharmonisan antar sesama masyarakat Indonesia. ${ }^{2}$ Contohnya dalam beberapa tahun terakhir ini, kita kerap dihadapkan pada kenyataan banyaknya konflik dan ketegangan-ketegangan itu telah menimbulkan banyak korban manusia dan harta benda. Sebagaimana dilaporkan banyak media, kita sebut diantaranya, kerusuhan Situbondo (1996), kerusuhan Sanggauledo (1997), kerusuhan Mei di Jakarta dan Solo (1998), kerusuhan Ketapang Jakarta (2000), kerusuhan Kupang (2000), kerusuhan Ambon (2000), kerusuhan Sambas (2000), kerusuhan Pontianak (2001), dan kerusuhan Sampit (2001).

Selain konflik yang melibatkan fisik, ada konflik yang bersifat

\footnotetext{
${ }^{1}$ Sitorus Magdalena. 2008. Pendidikan Berperspektif Globalisasi. Yogyakarta: Arruz Media

${ }^{2}$ Wahyu. 2006. Perubahan Sosial dan Pembangunan. Jakarta: Hecca Mitra Utama
} 
psikologis yakni konflik yang menimbulkan berbagai persoalan seperti yang dihadapi oleh bangsa Indonesia sekarang ini, berupa korupsi, kolusi, nepotisme, premanisme, perseteruan politik, kemiskinan, kekerasan, separatisme, perusakan fasilitas umum akibat pendemo serta perusakan lingkungan yang diakibatkan oleh perusahaan-perusahan tambang karena adanya kebijakan pemerintah pusat dan daerah yang mengatasnamakan kepentingan rakyat sehingga dalam hal ini mengakibatkan lunturnya nilai-nilai kemanusiaan untuk selalu menghormati hak-hak orang lain adalah bentuk nyata sebagai bagian dari realitas multikultural. $^{3}$

Di dalam kemajemukan yang menekankan pada kekuatan primordialisme, potensi konflik sangat dimungkinkan terjadi. Apabila konflik dibiarkan berlarut-larut dengan tanpa penanganan yang tepat, tak mustahil konflik tersebut semakin berkembang sehingga bisa mengancam integritas nasional dan keutuhan bangsa. Untuk itu, ideologi masyarakat majemuk yang menekankan pada primordialisme, terutama keanekaragaman kebudayaan atau suku bangsa harus digeser menjadi keanekaragaman kebudayaan atau ideologi multikultural.

Fenomena multikultural di Indonesia telah menarik para pakar untuk memberikan solusi mengenai aksi-aksi yang sampai saat ini banyak muncul, akibat dari gesekan antar etnis. Sebagai langkah antisipasi terjadinya konflikkonflik sosial karena adanya multi etnis di Indonesia tersebut, Pemerintah melalui Kementrian Pendidikan dan Kebudayaan mulai memasukkan pendidikan multikultural dalam kurikulum pengajaran yang mulai diterapkan tidak hanya di bangku Universitas tetapi juga diterapkan di bangku Sekolah- sekolah. ${ }^{4}$

\section{LANDASAN TEORI}

Pendidikan multikultural dapat dirumuskan sebagai wujud kesadaran tentang keanekaragaman kultural, hak-hak asasi manusia serta pengurangan atau pengahapusan berbagai jenis prasangka atau Prejudise untuk membangun suatu kehidupan masyarakat yang adil dan maju. Pendidikan multikultural juga dapat diartikan sebagai strategi untuk mengembangakan kesadaran atas

\footnotetext{
${ }^{3}$ Mahfud Choirul. 2010. Pendidikan Multikultural. Yogyakarta: Pustaka Pelajar

${ }^{4}$ Stavenhagen, Rudolfo. 1996. Education for a Multikultural World. Paris: Unesco
} 
kebanggaan seseorang terhadap bangsanya (the pride in one's home nation). ${ }^{5}$

Sebagai sebuah wacana baru, pengertian pendidikan multikultural sesungguhnya hingga saat ini belum begitu jelas dan masih banyak pakar pendidikan yang memperdebatkannya. Namun demikian, bukan berarti bahwa definisi pendidikan multikultural tidak nampak. Sebetulnya, sama dengan definisi pendidikan yang penuh penafsiran antara satu pakar lainnya di dalam menguraikan makna pendidikan itu sendiri. Hal ini juga terjadi pada penafsiran tentang arti pendidikan multikultural.

Mengutip pendapat Banks, bahwa pendidikan multikultural dapat diartikan sebagai pendidikan mengenai keragaman kebudayaan. Kemudian, Banks (2000:3) mendifinisikan pendidikan multikultural sebagai pendidikan untuk people of colour. Artinya, pendidikan multikultural ingin mengeksplorasi perbedaan sebagai keniscayaan (anugerah Tuhan/sunatullah).

Sejalan dengan pemikiran sebelumnya, Al Hakim dan suparlan berpendapat (2007:176), bahwa secara sederhana pendidikan multikultural dapat didefinisikan sebagai pendidikan tentang keragaman kebudayaan dalam merespon perubahan demografis dan kultural lingkungan masyarakat tertentu atau bahkan dunia secara keseluruhan. $^{6}$

Pendidikan multikultural sebagai perspektif yang mengakui realitas politik, sosial, dan ekonomi yang dialami oleh masing-masing individu dalam pertemuan manusia yang kompleks dan seragam secara kultur, serta merefleksikan pentingnya budaya, ras, seksualitas dan gender, etnisitas, agama, status sosial, ekonomi, dan pengecualian-pengecualian dalam proses pendidikan atau dengan cara saling menghargai dan menghormati atas realitas yang beragam (plural), baik latar belakang maupun basis sosio budaya yang melingkupinya.

Pemikiran tersebut sejalan dengan pendapat Freire (pakar pendidikan pembebasan), bahwa pendidikan bukan merupakan "menara gading" yang berusaha menjauhi realitas sosial dan budaya. Pendidikan, menurutnya harus mampu menciptakan tatanan masyarakat yang terdidik dan berpendidikan, bukan sebuah masyarakat yang hanya mengagungkan prestise sosial sebagai akibat dan

\footnotetext{
${ }^{5}$ Banks. 1993. Multikultural education: Historical Development, Dinension, and Praktic. Review of Research in Education

${ }^{6}$ Al Hakim dan Suparlan. 2007. Pendidikan Multikultural. Malang: Inka Print
} 
kemakmuran yang dialaminya. $^{7}$

Pendidikan multikultural dalam hal ini merupakan respons terhadap perkembangan keragaman populasi sekolah, sebagaimana tuntutan persamaan hak bagi setiap kelompok. Dalam dimensi lain, pendidikan multikultural merupakan pengembangan kurikulum dan aktivitas pendidikan untuk memasuki berbagai pandangan, sejarah prestasi dan perhatian terhadap orang-orang non Eropa. ${ }^{8}$ Secara luas, pendidikan multikultural itu mencakup seluruh siswa tanpa membedakan kelompok-kelompoknya yakni dalam hal ini adalah gender, etnic, ras, budaya, strata sosial dan agama.

Penelitian ini mempersiapkan sekolah dalam menyikapi perbedaan diantaranya adalah kepala sekolah mengadakan rapat kepada dewan guru beserta wakasek kesiswaan dan kurikulum untuk membahas pembuatan RPP yang meliputi rencana materi yang akan diajarkan dan tujuan yang ingin dicapai, adapun kurikulum yang dipakai oleh MTs Al Hamid Banjarmasin yaitu kurikulum KTSP Plus, kurikulum yang dalam pembelajaran menggunakan bahasa inggris. Peran serta wakil kepala sekolah bidang kesiswaan dalam membantu pelaksanaan pendidikan multikultural langsung diaplikasikan dalam bentuk kegiatan ekstrakulikuler. Evaluasi pendidikan multikultural di MTs Al Hamid Banjarmasin telah berhasil melaksanakan proses pembelajaran pendidikan multikultural. Hal ini terbukti dalam keseharian siswan dan guru meskipun siswa-siswinya berasal dari strata sosial yang berbeda namun dapat rukun dan saling menghargai tanpa memandang perbedaan. ${ }^{9}$

\section{METODOLOGI PENELITIAN}

Penelitian dilakukan di MTs Al Hamid Banjarmasin. Metode yang digunakan adalah kualitatif Naturalistik. Subjek penelitian adalah peserta didik kelas VIII tahun Pelajaran 2015/2016 yang berjumlah 100 orang, dewan guru serta kepala sekolah yang ada di sekolah MTs Al Hamid Banjarmasin. Pengumpulan data diperoleh melalui angket serta uji sosiometri data yang

\footnotetext{
${ }^{7}$ Mahfud Choirul. 2010. Pendidikan Multikultural. Yogyakarta: Pustaka Pelajar

${ }^{8}$ Banks. 1993. Multikultural education: Historical Development, Dinension, and Praktic. Review of Research in Education

${ }^{9}$ Ngalimun. 2014. Strategi dan Model Pembelajaran. Yogyakarta: Aswaja Pressindo
} 
diperoleh kemudian dianalisis naratif. Jenis sumber data dalam penelitian di pilih melalui secara purposive dan snowball sampling. Penentuan sumber data masih bersifat sementara dan akan berkembang kemudian setelah penelitian di lapangan. Sumber data pada tahap awal memasuki lapangan dipilih orang yang memiliki power dan otoritas pada objek yang diteliti, sehingga mampu membuka pintu ke mana saja peneliti akan melakukan pengumpulan data, sumber data yang diteliti ada 2 guru yakni guru PKn, Dra. Hj. Sriwahyuni, dan Bp. Aksah, S.Pd, Siswa yang diteliti 30 siswa.

Istilah pengambilan sampel dalam penelitian kualitatif digunakan dengan penuh kehati-hatian. Penelitian kualitatif tujuan pengambilan sampel adalah untuk mendapatkan informasi sebanyak mungkin bukan untuk melakukan generalisasi. Pengambilan sampel dikenakan pada situasi, subjek, informan, dan waktu. Teknik pengumpulan data peneliti menggunakan teknik observasi, wawancara, angket dan dokumentasi, serta studi Pustaka. Pertanyaan-pertanyaan tentang pandangan, sikap, keyakinan subjek atau diskusi diajukan secara bebas dan rahasia kepada subjek.

\section{HASIL PENELITIAN DAN PEMBAHASAN}

\section{A. Perencanaan Pendidikan Multikultural dalam Kurikulum PKn}

\section{Sekolah}

MTs Al Hamid Banjarmasin merupakan sekolah yang memiliki siswa-siswi beragam, baik dalam etnik, suku bangsa, dan agama. Keberagaman ini merupakan faktor ketidaksengajaan sekolah dalam perekrutan/penerimaan siswasiswi baru.

Selain itu peneliti melihat jumlah murid yang sekolah di MTs Al Hamid Banjarmasin 789 Siswa terdiri dari 26 kelas, mengingat jumlah yang cukup banyak sehingga peneliti memutuskan jumlah responden untuk mengisi angket yaitu 100 orang yang dilaksanakan pada kelas VIII.

Perencanaan sekolah MTs Al Hamid Banjarmasin mempersiapkan siswasiswinya unggul dalam akademik dan tata krama dalam ruang lingkup kebhinekaan yang mana dalam hal ini hidup dalam keberagaman suku bangsa saling hormatmenghormati, tenggang rasa, menghargai sikap dan prilaku siswa yang lain serta menanamkan jiwa kesamaan hak sebagai warga negara dalam hal menuntut ilmu. 
E-ISSN : 2580-7056, ISSN : 2580-7064

Pascasarjana IAIN Palangka Raya

\section{Wakil Kepala Sekolah Bidang Kurikulum}

Menyikapi Perencanaan pendidikan multikultural MTs Al Hamid Banjarmasin mempersiapkan kurikulum, adapun kurikulum yang di gunakaan yakni kurikulum yang di rancang melalui pendekatan keberagaman yaitu kurikulum KTSP plus yang mana kurikulum ini mempunyai karakter penggunaan dua bahasa/bilingual yaitu Bahasa Indonesia dan Bahasa Inggris di dalam kesehariannya.

Kurikulum ini diterapkan kepada guru semua bidang studi yang ada di ajarkan MTs Al Hamid Banjarmasin, dengan maksud bahwa kurikulum yang ada sebagai sekolah unggulan di bidang akademik.

\section{Guru}

Perencanaan guru dalam pendidikan multikultural di MTs Al Hamid Banjarmasin ini adalah mempersiapkan komponen pembelajaran yang akan di siapkan diantaranya silabus dan RPP, di dalam RPP ini guru MTs Al Hamid Banjarmasin menggunakan RPP Karakter, yang mana dalam RPP ini ada III kali pertemuan tatap muka antara siswa dan guru, dengan materi ajar pelaksanaan demokrasi di berbagai aspek kehidupan yang menjelaskan ada III standar kompetensi dan III Komptens Dasar.

Standar kompetensi pada pertemuan pertama guru menjelaskan pengertian demokrasi, sejarah perkembangan demokrasi, serta menguraikan macam-macam demokrasi sehingga diharapkan dari RPP ini mampu memberikan karakter kepada siswa-siswi mampu percaya, berani memberikan argumentasi di masyarakat, ketulusan menghargai pendapat orang lain, integritas, dan mampu menjadi manusia yang berjiwa pancasila/kewarganegaraan, kemudian metode yang digunakan oleh guru adalah ceramah bervariasi, tanya jawab, serta diskusi.

Dari hasil wawancara peneliti dengan guru mata pelajaran PKn di MTs Al Hamid Banjarmasin dapat di ambil beberapa poin penting yakni:

a. Sekolah MTs Al Hamid Banjarmasin merupakan sekolah yang siswa-siswi nya saling hormat-menghormati satu dengan yang lainnya serta menghargai keberagaman baik suku bangsa, etnik, dan agama.

b. Dalam perekrutan siswa baru pihak sekolah menyelenggarakan melalui sistem Online sehingga dalam hal ini membuka peluang besar kepada calon siswa- 
siswi di manapun berada untuk mengeyam bangku pendidikan di sekolah MTs Al Hamid Banjarmasin.

c. MTs Al Hamid Banjarmasin selain mengetumakan pendidikan yang unggul dan berkualitas juga mengutamakaan jalinan tali asih berupa Gerakan Orang Tua Asuh hal ini pelakasanannya pada tahun 2010 .

d. Kurikulum yang disajikan oleh MTs Al Hamid Banjarmasin dalam menyikapi keberagaman yakni menggunakan KTSP Plus dan kurikulum Akselerasi (percepatan).

\section{B. Pelaksanaan Pendidikan Multikultural dalam Kurikulum Pendidikan PKn}

\section{Wakil Kepala Sekolah Bidang Kesiswaan}

Peran serta wakil kepala sekolah bidang kesiswaan menunjukan bahwa setiap elemen sekolah bertindak kerjasama dalam hal kemajuan proses belajar mengajar, adapun tugas dari wakil kepala sekolah bidang kesiswaan diantaranya adalah mengadakan kegiatan ekstrakulikuler, peringatan hari-hari besar keagamaan, penerbitan majalah dinding serta mengadakan upacara bendera.

Hal ini mengindikasikan bahwa perencanaan pendidikan multikultural di MTs Al Hamid Banjarmasin secara tidak langsung sudah dilaksanakan oleh Sekolah dalam hal ini adalah perangkat sekolah.

\section{Guru Bidang Studi}

Objek penelitian yang dilakukan oleh peneliti ialah pada kelas VIII di mana kelas tersebut terdiri dari 9 kelas selain itu kelas tersebut siswa-siswinya beragam suku bangsa, agama serta strata sosial, sehingga dalam hal ini peneliti lebih banyak melakukan wawancara serta dokumentasi dengan ibu Dra. Hj. Sri Wahyuni.

Pelaksanaan pendidikan multikultural yang ada di MTs Al Hamid Banjarmasin yang dilakukan oleh guru PKn salah satunya ialah menerapkan RPP karakter karena dirasa oleh guru lebih mudah dan siswa lebih mudah mencerna materi. Sehingga peneliti sempat melakukan beberapa pertanyaan kepada salah satu guru PKn, seiring berjalannya waktu saya dengan MTs Al Hamid Banjarmasin saat ini di tunjuk oleh pemerintah dalam hal ini disdik MTs Al Hamid Banjarmasin ini di tunjuk untuk menerapkan kurikulum 2013. 
E-ISSN : 2580-7056, ISSN : 2580-7064

Pascasarjana IAIN Palangka Raya

\section{Siswa}

Data yang diperoleh 30 orang siswa dari 100 orang pada saat meneliti melalui sosiometri dapat ditemukan ada beberapa responden yang melakukan ejekmengejek antar siswa dengan siswa yang lain hal ini terjadi disela-sela jam pelajaran atau jam istirahat, suasana demikian terbawa pada saat masuk kembali jam pelajaran. sehingga guru mengetahui akan hal ini dan langsung menegur serta menasehati, kemudian memberikan pandangan kepada siswa-siswi akan pentingnya hidup saling hormat-menghormati antar suku bangsa dan negara serta pelaksanaan demokrasi di berbagai aspek kehidupan.

Selain itu ada beberapa hal yang penting dalam pelaksanaan pendidikan multikultural didalam kurikulum PKn yaitu;

a. Wakil kepala sekolah bidang kesiswaan menanamkan jiwa toleransi, humanis kepada siswa-siswinya ikut dalam kegiatan ekstrakulikuler yang mana dengan maksud untuk memahamkan kepada siswa-siswi saling membaur antara siswa satu dengan yang lainnya. Sehingga dalam hal ini terjalin suasana menyenangkan disekolah serta nantinya siswa-siswi bisa beriteraksi dan aktif dalam hubungan sosial di masyarakat.

b. Walaupun MTs Al Hamid Banjarmasin di tunjuk oleh pemerintah dalam hal ini disdik untuk menerapkan kurikulum 2013 akan tetapi hal ini hanya beberapa kelas yang melaksanakannya yaitu kelas VII, sedangkan untuk kelas VIII dan IX memakai kurikulum yang lama yaitu kurikulum KTSP.

c. Di dalam pelaksanaan pendidikan multikultural ditemukan oleh guru bahwa siswa pada saat jam pelajaran berlangsung dan kerja kelompok siswa melakukan kegiatan saling ejek-mengejek adapun ejekan tersebut hanya insidensil akan tetapi bila berlansung berlarut-larut akan menimbulkan masalah yang cukup besar, guru mengetahui hal itu langsung menasehati dan memberikan pandangan kepada siswa tersebut untuk tidak mengulanginya lagi.

\section{Evaluasi Pendidikan Multikultural di dalam Kurikulum PKn}

\section{Wakil Kepala Sekolah Bidang Kurikulum}

Setelah diketahui bahwa peran elemen penting dalam menunjang pendidikan multikultural ternyata banyak yang terlibat didalam hal ini adalah 
wakil kepala sekolah bidang kurikulum, bidang ini merupakan suatu bidang yang sangat strategis dalam jalannya sistem pembelajaran.

Bila dilihat hal demikian betapa pentingnya hubangan antara kepala sekolah dengan wakil kepala sekolah bidang kurikulum, wakil kepala sekolah bidang kurikulum dengan wakil kepala sekolah bidang kesiswaan, serta wakil kepala sekolah bidang kesiswaan dengan guru bidang studi.

\section{Wakil Kepala Sekolah Bidang Kesiswaan}

Peran serta wakil kepala sekolah bidang kesiswaan sangat lah membantu kepada guru bidang studi PKn dalam hal memecahkan masalah antara siswa yang satu dengan yang lainnya. Hal ini di ungkapkan oleh Dra. Hj. Sri Wahyuni disela- sela wawancara dengan peneliti, menurut ibu apakah ada peran serta wakil kepala sekolah bidang kesiswaan dalam proses belajar mengajar.

\section{Guru Bidang Studi}

Peran guru yang sebagai figur di guguh dan di tiru oleh siswa-siswi sangatlah berhasil menanamkan nilai-nilai yang sangat penting terhadap tumbuh kembangnya tingkah laku seorang siswa di kemudian hari, sehingga menghasilkan generasi- generasi yang berdemokrasi, toleransi, disiplin, kreatif dan komunikatif.

\section{Siswa}

Siswa-siswi yang berada di MTs Al Hamid Banjarmasin secara keseluruhan merupakan siswa yang beragam etnik, suku bangsa, agama serta strata sosial, dari data yang diproleh peneliti dari sekolah siswa yang berjumlah 300 orang, objek penelitian pada kelas VIII menggunakan uji sosiometri diperoleh hasil bahwa masih ada beberapa siswa yang saling ejek dan merendahkan satu sama lain, namun dalam hal ini guru Pkn sudah memberikan nasehat dan teguran agar mereka saling hormat menghormati antar sesama siswa.

Dari hasil evaluasi pendidikan multikultural di dalam kurikulum PKN di MTs Al Hamid Banjarmasin dapat ditemukan bahwa:

a. Keterlibatan elemen sekolah MTs Al Hamid Banjarmasin yakni kepala sekolah, wakil kepala sekolah bidang kurikulum, wakil kepala sekolah kesiswaan serta guru bidang pelajaran sangat peran penting dalam membina/membentuk 
pendidikan multikultural ke siswa-siswi MTs Al Hamid Banjarmasin yang identik dengan Multi budaya, sehingga hal ini guru di arahkan dalam pembuatan RPP.

b. Peran serta wakil kepala sekolah bidang kesiswaan dalam pembentukan pendidikan multikultural membantuk guru mengetahui kelas mana-mana yang perlu penanganan secara berkelanjutan supaya tidak terjadi masalah dikemudian hari.

\section{PEMBAHASAN HASIL PENELITIAN}

\section{A. Perencanaan Pendidikan Multikultural dalam Kurikulum PKn}

\section{Sekolah}

Hasil penelitian melalui wawancara menyebutkan MTs Al Hamid Banjarmasin mempunyai jumlah siswa sebanyak 789 dan tiap tahun nya menerima siswa baru 100 siswa adapun penerimaan nya melalui sistim online berikut paparan hasil wawancara peneliti dengan kepala sekolah.

Hal ini sesuai apa yang di sampaikan oleh UU Pendidikan No 2003 sistim pendidikan nasional, Bab III, Pasal ke IV, di dalam pasal IV ini menjelaskan prinsip penyelenggaraan pendidikan, pendidikan diselenggarakan secara demokrasi dan berkeadilan serta tidak diskriminasi dengan menjunjung tinggi hak asasi manusia, nilai agama, nilai kultur dan kemajemukan bangsa, pendidikan diselenggarakan sebagai satu kesatuan yang sistemik dengan sistim yang terbuka dan multimakna

\section{Wakil Kepala Sekolah Bidang Kurikulum}

Menyikapi perencanaan pendidikan multikultural MTs Al Hamid Banjarmasin yakni mempersiapkan kurikulum, adapun kurikulum yang digunakan yakni kurikulum yang dirancang melalui pendekatan keragaman yaitu KTSP Plus yang mana kurikulum ini mempunyai karakter penggunaan dua bahasa yakni bahasa indonesia dan bahasa inggris.

Sehingga dalam hal ini Suratno (2009) mendefinisikan kurikulum merupakan seperangkat pengalaman pembelajaran yang terencana dan terarah, yang disusun melalui proses rekonstruksi pengetahuan dan pengalaman yang sistematis di bawah pengawasan lembaga pendidikan agar pembelajaran dapat terus memiliki minat untuk belajar sebagai bagian dari kompetensi social 
E-ISSN : 2580-7056, ISSN : 2580-7064

Pascasarjana IAIN Palangka Raya

pribadinya. $^{10}$

\section{Guru}

Perencanaan Guru bidang studi PKn bekerjasama dengan wakil kepala sekolah bidang kurikulum merancang Rencana Pelaksanaan Pembelajaran yang berbasis pendidikan multikultural. Dari tujuan pendidikan multikultural ini direncanakan kurikulum dan keputusan-keputusan instruksional yang akan dilaksanakan. Hal demikian senada di sampaikan oleh Syaiful (2000), pembelajaran adalah suatu proses dimana lingkungan seseorang dikelola secara disengaja untuk memungkinkan ia turut serta dalam tingkah laku tertentu, sehingga dalam kondisi-kondisi khusus akan menghasilkan respons terhadap situasi tertentu juga. ${ }^{11}$

\section{B. Pelaksanaan Pendidikan Multikultural di dalam Kurikulum PKn}

\section{Wakil Kepala Sekolah Bidang Kesiswaan}

Dalam pelaksanaan pendidikan multikultural di MTs Al Hamid Banjarmasin peran serta wakil kepala sekolah bidang kesiswaan mempunyai kontribusi yang sangat besar untuk mencapai keberhasilan sehingga hal ini adalah hasil wawancara peneliti dengan responden.

Sehingga sejalan dengan pendapat mahfud (2009) bahwa tujuan pendidikan multikultural akan mengarahkan anak didik untuk bersikap dan berpandangan toleransi dan inklusif terhadap realitas masyarakat yang beragam, baik dalam hal budaya, suku, ras, etnis maupun agama. Paradigma ini di maksud untuk apresiatif terhadap budaya orang lan, perbedaan dan keberagaman merupakan kekayaan khazanah bangsa.

\section{Guru Bidang Studi}

Hasil wawancara dan observasi ditemukan bahwa pada saat suasana belajar kelompok didalam kelas ditemukan siswa saling ejek-mengejek, antara satu dengan yang lainnya perkataan yang di ejek berupa kata-kata sombong, nama orang tua, suku bangsa akan tetapi hal demikian langsung diketahui oleh guru PKn dan langsung menasehatinya. Sehinga sependapat dengan Sigmund Freud yang terkenal psikologi Seorang adanya suatu masalah bagaimana

\footnotetext{
${ }^{10}$ Suratno. 2009. Assesmen Pembelajaran di Sekolah. Yogyakarta: Multi Pressindo

${ }^{11}$ Djamarah, Syaiful Bahri. 2000. Guru dan Anak Didik dalam Interaksi Edukatif. Jakarta: Renika Cipta
} 
menyelesaikan masalah tanpa ada yang merasa tersakiti.

\section{Evaluasi Pendidikan Multikultural dalam Kurikulum PKn}

\section{Wakil Kepala Sekolah Bidang Kurikulum}

Hasil wawancara peneliti dengan wakil kepala sekolah di dapat sebuat data/ informasi keterjalinan kerjasama antara wakil kepala sekolah bidang kurikulum dan wakil kepala sekolah bidang kesiswaan.

Sesuai penyampaian yang disampaikan oleh Franklin Bobbit kehidupan manusia terbentuk oleh sejumlah kecakapan, diperoleh melalui pendidikan yakni penguasaan pengetahuan, keterampilan, sikap, kebiasaan, apresiasi tujuan Kurikulum. Keseluruhan tujuan \& pengalaman menjadi bahan kajian teori kurikulum.

\section{Wakil Kepala Sekolah Bidang Kesiswaan}

Peran serta wakil kepala sekolah bidang kesiswaan membantu kepada guru bidang studi dalam memecahkan masalah antara siswa yang satu dengan yang lainnya, sehingga diproleh data.

Pandangan ini sesuai dengan pendapat Hadari Nawawi berpendapat bahwa kepemimpinan adalah kemampuan menggerakkan, memberikan motivasi dan mempengaruhi orang-orang agar bersedia melakukan tindakan-tindakan yang terarah pada pencapaian tujuan melalui keberanian mengambil keputusan tentang kegiatan yang dilakukan.

\section{Guru Bidang Studi}

Peran guru sebagai figur yang diguguh dan ditiru oleh siswa-siswi di MTs Al Hamid Banjarmasin sangat berhasil menanamkan nilai-nilai penting terhadap tumbuh kembangnya tingkah laku siswa dikemudian hari, sehingga menghasilkan generasi-generasi yang berdemokrasi, disiplin, kreatif dan komunikatif. Penilaian lebih menekankan kepada proses pembuatan keputusan terhadap sesuatu ukuran baik-buruk yang bersifat kuantitatif. Sedangkan pengukuran menekankan proses penentuan kualitas sesuatu yang dibandingkan dengan satuan ukuran tertentu.

\section{KESIMPULAN}

1. Bentuk persiapan-persiapan sekolah dalam menyikapi perbedaan itu diantaranya adalah kepala sekolah mengadakan rapat kepada dewan guru beserta 
wakasek kesiswaan dan kurikulum untuk membahas pembuatan Rencana Pelaksanaan Pembelajaran (RPP) yang meliputi rencana tentang materi yang akan diajarkan dan tujuan yang ingin dicapai agar proses pembelajaran berjalan lancar sesuai yang diharapkan, selain itu pula MTs Al Hamid Banjarmasin juga menyiapkan segala bentuk formulasi kegiatan yang akan dilaksanakan dalam proses pembelajaran diantaranya menyiapkan guru yang berkompeten sesuai latar belakang pendidikan, menyiapkan siswa-siswa yang berkualitas dilihat dari nilai NEM melalui sistem Online hal ini dilaksanakan untuk menjaring siswa-siswi yang lebih berkualitas.

2. Peran serta wakil kepala sekolah bidang kesiswaan dalam membantu pelaksanaan pendidikan multikultural di sekolah MTs Al Hamid Banjarmasin diaplikasikan dalam bentuk kegiatan ekstrakulikuler, siswa di ikut sertakan kegiatan seperti Palang Merah Remaja (PMR), Pramuka, mempringati hari-hari besar keagamaan, jumat bersih, paskibraka, olah raga, kerohanian, serta kooperasi sekolah, selain itu peran seorang guru diaplikasikan dalam proses pembelajaran dalam hal ini pelajaran PKn dengan bahan materi ajar pelaksanan demokrasi diberbagai aspek kehidupan.

3. Evaluasi pendidikan multikultural di MTs Al Hamid Banjarmasin dapat disimpulkan bahwa berhasil melaksanakan proses pembelajaran pendidikan multikultural. Hal ini terbukti dalam keseharian siswa dan guru di sekolah meskipun siswa-siswi berasal dari latar belakang agama, suku bangsa, ras, jenis kelamin, strata sosial yang berbeda-beda siswa-siswi MTs Al Hamid Banjarmasin dapat hidup rukun dan saling menghargai tanpa memandang perbedaan. 
E-ISSN : 2580-7056, ISSN : 2580-7064

Pascasarjana IAIN Palangka Raya

\section{DAFTAR PUSTAKA}

Al-Hakim, Suparlan. 2007. Pendidikan Multikultural. Malang: Inka Print.

Banks, JA, 1993. Multicultural Education: Historical Development, Dimensions and Practice. Review of Research in Education.

Djamarah, Syaiful Bahri. 2000. Guru Dan Anak Didik Dalam Interaksi Edukatif. Jakarta: Rineka cipta.

Mahfud, Choirul. 2010. Pendidikan Multikultural. Yogyakarta: Pustaka Pelajar.

Ngalimun. 2014. Strategi dan Model Pembelajaran. Yogyakarta: Aswaja Pressindo

Stavenhagen, Rudolfo, 1996. Educational for a Multikultural World. Paris: UNESCO.

Sitorus, Magdalena. 2008. Pendidikan Berperspektif Globalisasi. Yogyakarta: ArRuzz Media Group.

Suratno, et all. 2009. Assesmen Pembelajaran Di Sekolah. Yogyakarta: Multi Presindo.

Wahyu, 2006. Perubahan Sosial Dan Pembangunan. Jakarta: Hecca Mitra Utama. 